\title{
Immunosenescence and the gut microbiota: The role of probiotics and prebiotics
}

\author{
Ruth E. Toward*, Gemma E. Walton and Glenn R. Gibson \\ Department of Food and Nutritional Sciences, The University of Reading, Whiteknights, Reading, UK
}

Received 24 October 2012

Accepted 22 November 2012

\begin{abstract}
The global population is becoming increasingly older presenting medical and economic challenges to society. One factor associated with the aging process is immunosenescence, which may be defined as the decline in immunity with age, and represents a potential causative factor for many age related illnesses. The profile of the gut microbiota is also known to alter with aging and these changes have been linked the declines in the immunity observed in immunosenescence. For example, above the age of 60 years populations of bifidobacteria have been observed to decrease markedly, leading to a reduction in the inhibition of the growth of some pathogens and potentially an increase in the susceptibility to infections. As such, an interest exists in attempting to reverse their decline in elderly individuals, through the use of both probiotics and prebiotics. Both approaches have shown to be encouraging in altering microbiota profiles beneficially and in reducing immunosenescence by reducing the colonisation potential of pathogens and counteracting chronic inflammation. The current review will give an overview of the process of immunosenescence and its role in disease, detail how the microbiota are involved in its progression and highlight data suggesting that pre- and probiotics may counteract these age-related events.
\end{abstract}

Keywords: Age, gut, bacteria, bifidobacteria, fermentation, immunity, metabolism, probiotics, prebiotics

\section{Aging and immunosenescence}

Immunosenescence is a process that may relate to two physiological responses: 1) adaptive immune responses to pathogen exposure, or 2) the deterioration of the activity of the immune system and/or an increased susceptibility to pathogen invasion brought about by the ageing process. The former, results in the depletion of the reservoir of naive $T$ cells over time by contact with pathogens [1]. However, for the purpose of this review, we will focus on the latter as it is likely to become more prevalent due to increases in aged populations in developed and developing countries. For example, the population of the European Union (EU) is forecast to reach 517 million in 2060 with approximately one third of the citizens being aged 65 and over [2, 3] (See Fig. 1). Although this is desirable, an ageing population also presents challenges to society such

*Corresponding author: Ruth E. Toward, Department of Food and Nutritional Sciences, The University of Reading, Whiteknights, Reading, UK. Tel: +44 11 89357033; Fax: +44 11 89267917; E-mail: r.e.toward@pgr.reading.ac.uk. as increased pressure on long-term health and social care. For example, public spending on long-term care is projected to double, increasing from $1.8 \%$ of gross domestic product (GDP) in 2010 to $3.4 \%$ of GDP in 2060 in the EU as a whole [3]. Consequently, the quality of life of this increasing share of the population is of vital concern. The elderly are known to suffer from a host of age-related diseases, such as atherosclerosis, Alzheimer's dementia, diabetes mellitus, and osteoporosis many of which are thought to be mediated by a dysfunction of the immune system [4]. A loss of immune function with aging can have a variety of detrimental effects, such as the failure of the host in recognizing its own cells and the inability of the immune system to detect and correct cell defects, although the most significant is the inability to raise a correct immune response to invading pathogens, leading to increased susceptibility to infection [5]. This review will outline the primary factors involved in age-related losses in immune function and then discuss potential novel approaches to restore function using pre- and probiotics. 


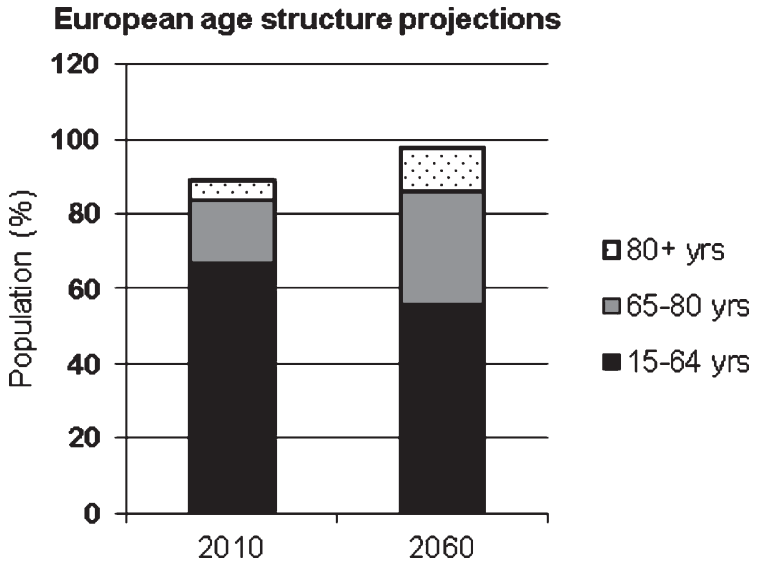

Fig. 1. Population age structure: 2010-2060. Data source [3].

As we grow older, epithelial barriers of the skin, lung and gastrointestinal tract degrade enabling increased invasion of delicate mucosal tissues by pathogens [6]. A significant reduction in humoral response (immune response that is mediated by $\mathrm{B}$ cells) is therefore observed following vaccination or infections [7]. The immune system itself may be divided into various parts: the innate part, consisting of cytokines, neutrophils, macrophages, natural killer (NK) cells and dendritic cells and the adaptive part, represented by $\mathrm{T}$ and B-cells [8]. The adaptive immune system consists of antigen-recognising lymphocytes (naïve lymphocytes) and antigen-experienced lymphocytes (memory lymphocytes), which detect foreign body (or antigen) invasion. Major changes to the adaptive system through immunosenescence include a decline in production of $\mathrm{CD} 3+\mathrm{T}$ cells, naive $\mathrm{T}$ cells and $\mathrm{B}$ cells reducing the ability to detect antigens [9]. The innate system on the other hand, is less specialised and defends against pathogens more generically.
Extensive research has indicated that the adaptive immune system is subject to severe deterioration with age $[10,11]$, although there is limited information on the impact on cells of the innate system. However, recent research and clinical investigations have highlighted several cells of innate immunity that alter in number and function with age and therefore may help to characterise immunosenescence in aging populations. The most significant of these are presented in Table 1 .

\section{Immune biomarkers of immunosenescence}

The age-associated rise in IL-6 may stimulate an increase in inflammatory proteins such as C-reactive protein (CRP) [12], a known activator of the complement system that aids the ability of antibodies to destroy pathogens. As such, CRP levels are used as a marker of inflammation in response to infection and data indicate that subjects with higher basal levels of CRP have an elevated risk of mortality. For example, in a sample population of 1,293 healthy older persons, subjects with high circulating levels of IL- 6 and C-reactive protein were 2.6 times more likely to die during follow-up (4.6 y) than those with low levels of both [13]. It is has not however been determined whether CRP acts simply as a marker for chronic disease, or whether it plays a role in the onset of diseases, such as cardiovascular disease (CVD). Another marker of inflammation is calprotectin; a calcium and zinc binding protein present in the cytosol of neutrophils. In response to inflammation, neutrophils release calprotectin, giving rise to apoptosis inducing and anti-microbial properties. By binding to zinc, calprotectin inhibits zinc dependent enzymes that are important in the inflammation process [14].

Table 1

Immune defects associated with ageing

\begin{tabular}{lll}
\hline Cell type & Changes & Author \\
\hline Neutrophils & Circulating cell numbers $\Downarrow$ & {$[101]$} \\
& Superoxide production $\Downarrow$ & {$[102]$} \\
& Phagocytic capacity $\Downarrow$ & {$[103]$} \\
NK Cells & Production of IFN- $\gamma$ after stimulation with IL-2 $\Downarrow$ & {$[104,105]$} \\
& Activity on a per cell basis $\Downarrow$ & {$[106]$} \\
Monocytes/macrophages & Mature NK cell numbers $\Uparrow$ & Production of IFN- $\alpha \Downarrow$ \\
& Production of IL-1, IL-6, TNF- $\alpha \Uparrow$ (pro-inflammatory cytokines) & {$[107]$} \\
& Production of IL-10 $\Uparrow$ (anti-inflammatory cytokine) & {$[108]$} \\
\hline
\end{tabular}


Furthermore, it is also capable of preventing microbial growth through competition for zinc providing a mechanism in defending against pathogens [14]. Calprotectin levels are used as a gold standard biomarker in testing for inflammatory diseases such as Crohn's disease, cancer and ulcerative colitis and a significant positive correlation between faecal calprotectin and age has been identified in a group of 320 mixed sex 50-70 year olds [15]. This supports the theory that immunosenescence leads to both an age-associated decline in immune function and a corresponding increase in inflammation, which is likely to lead to an increased secretion of both CRP and calprotectin.

In addition, oxidative stress has also been identified as a biomarker of immunosenescence, as the advancement of age in healthy individuals is associated with a decrease in antioxidant defence and increased oxidative damage [16]. The increased production of reactive oxygen species (ROS) such as superoxide from neutrophils and a corresponding loss of antioxidant protection, characterises oxidative stress. During the respiratory burst, superoxide production is unregulated as a beneficial defence mechanism in response to invading pathogens, however production of ROS elsewhere in the body, outside of immune sites, can cause disturbances in the redox balance of tissues resulting in widespread damage to the lipids, proteins and DNA of host cells [17]. This may contribute to a number of diseases such as arthrosclerosis, heart failure, Parkinson's and Alzheimer's disease. As well as increasing the incidence of disease and impairing physiological function, oxidative stress is also thought to play a critical role in the ageing process itself [18].

\section{The microbiota: A novel mediator of age-related impairments in the immune system}

Various changes throughout the GI tract may play a role in age-associated changes in the profile of the microbiota. These include major structural/sensory changes in the upper GI tract such as the loss of teeth, inefficient chewing and thus poor digestion of food [19], and reduced olfactory and gustatory sensitivity, restricting appetite and food selection [20]. In the stomach, recurrent atrophic gastritis (chronic inflammation of the stomach) may result in reduced stomach acid, leading to bacterial overgrowth [21,22]. Changes in GI tract transit, such as reduced intestinal motility, may also slow digestion and lead to constipation [23]. Most notably with respect to immune changes, increased intestinal mucosal permeability (e.g. leaky gut syndrome) may lead to significant damage to the intestinal lining, allowing bacteria, toxins, undigested nutrients and waste to leak from the intestines into the blood stream causing serious/chronic autoimmune response, particularly if these toxins overburden the liver [24]. Finally, the loss of immune function common in normal aging can lead to impaired immune responses towards certain bacterial species, resulting in recurrent infection [25] and chronic inflammation in the lower gut.

It is estimated that around 1000-1500 different species of bacteria exist in the gut of healthy adults, the majority of which are strict anaerobes [26]. There are an array of major bacterial groups that exist within the large intestine including: Bifidobacterium, Clostridium, Bacteroides, Eubacterium, Escherichia, Enterococcus, Streptococcus and Klebsiella [27]. It has become clear that a distinct alteration in the composition of intestinal microbiota is occurs during aging, with data suggesting that while bifidobacteria [28] and bacteroides [29] numbers decrease, lactobacilli, enterobacteria, staphylococci and streptococci have been noted to increase [29, 30] (Fig. 2). Data emanating from a large scale European sample set has indicated that bacteroides remain unchanged among age groups, although this discrepancy may be due to geographical differences which are known to strongly influence agerelated changes of the gut microbiota [31]. Among the Firmicutes, the Clostridium coccoides/Eubacterium rectale group (Clostridium cluster IV) have been noted to decrease in aged Japanese 74-94 years [32], Italians $>60$ years [31], centenarians [33] and Finnish $>70$ years [34], with just one exception, in Germans $>60$ years [31].

Shifts in dominant species within bacterial groups

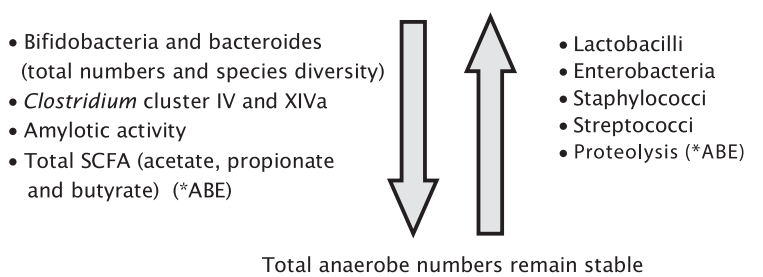

Fig. 2. Key changes to the intestinal microbiota observed in general elderly populations. Adapted from [56]. *ABE = antibiotic-treated elderly. 


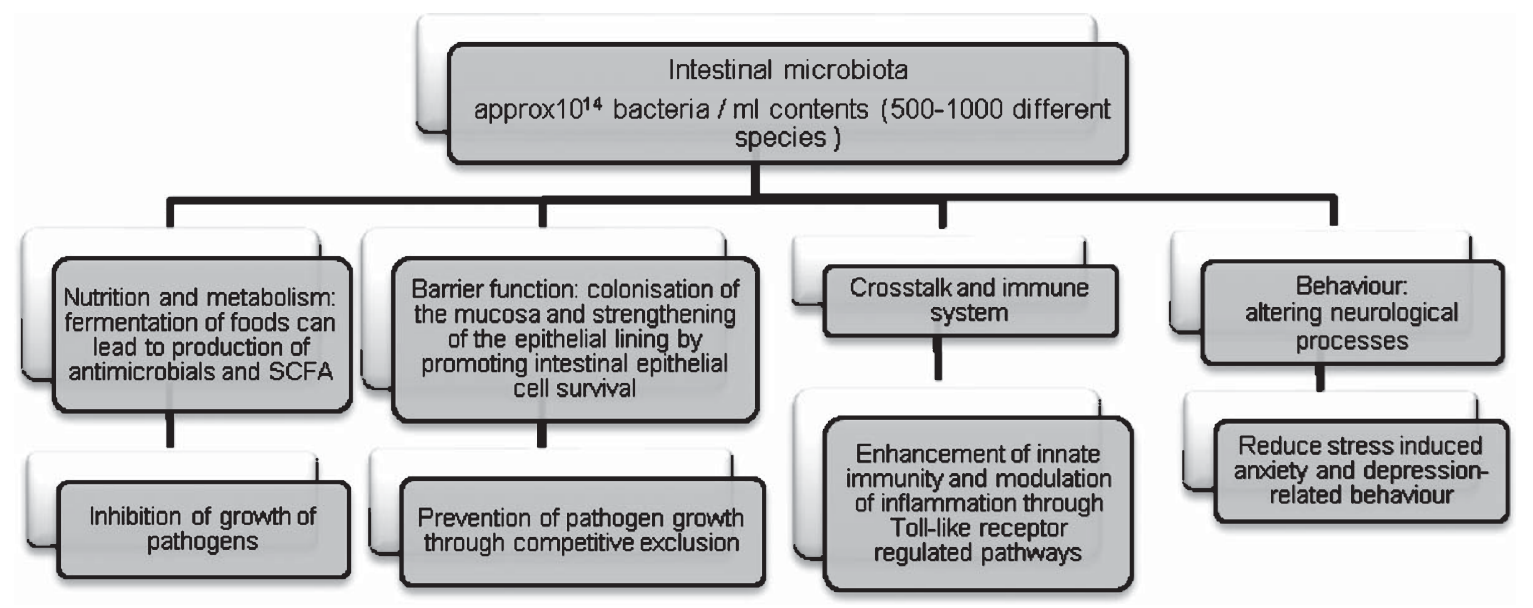

Fig. 3. The homeostatic role of the intestinal microbiota. Adapted from [99].

Gastrointestinal deteriorations and frequent use of antibiotics may account for some of these changes in the gut microbiota in the elderly [35], although it is thought that diet remains to be a lead causal factor. Claesson and colleagues recently examined diet-induced differences in the microbiota composition with age and revealed individuals with a healthy varied diet exhibited a more diverse gut microbiota than those with a less varied diet [36]. This lack of microbial diversity may lead to increased pathogenic and toxic burdens, increased bowel cancer risk, and disorders of liver function with age [37, 38].

As well as diet, it is also possible that increases in both intestinal inflammation and systemic inflammation can play a role in mediating these changes in the gut microbiota and composition. This suggests a vicious cycle in which the compromised balance of the gut microbiota may accelerate inflammation and this inflammation may further contribute to changes in the bacterial profile [39]. One of the many characteristics of immunosenescence is chronic low-grade inflammation termed 'inflamm-ageing' [40]. In a healthy adult GI tract, a homeostatic equilibrium is shared between the microbiota and the immune system (Fig. 3). However, inflamm-ageing and age-related changes in the symbiotic microbiota may undermine this balance. The maintenance of a 'healthy' gut microbiota structure during ageing could help in delaying the inflammageing process. Faecalibacterium, Bifidobacterium and Lactobacillus are known to down-regulate the pro-inflammatory response [41-44] and Bacteroides thetaiotaomicron may indirectly prevent the transcription of pro-inflammatory genes [45]. This link between age, the gut microbiota and inflammatory status has been demonstrated in a study with 3 cohorts: young adults (mean age $30 \mathrm{yrs}$ ), elderly (70 yrs) and centenarians (100 yrs) from Northern Italy. Data indicated that that centenarians had significantly more compromised gut microbiota and pronounced inflammation compared to the other groups, which might be explained by decreases in Faecalibacterium prauznitzii and relatives (butyrate producers with reported anti-inflammatory properties) in centenarians, leading to an inflammatory response [33].

\section{Mediators of bacterial-derived immune regulation}

Metabolic status, including immune regulation, can be influenced by a series of intrinsic and extrinsic factors, including those that are genetic and environmental (such as the gut microbiota) [46] and may provide knowledge on the aetiology of disease [47]. Age-related changes in microbial populations in the gut will also lead to changes in the production of short chain fatty acids (SCFA). Fermentable fibres present in vegetables, fruits and cereals, which reach the colon, are converted into SCFA by the colonic microbiota, with the three major ones produced being acetate, propionate and butyrate. Other SCFA's and organic acids such as valerate, caproate, succinate, malonate, fumarate, formate are also produced but to a lesser extent [48]. In vitro and animal studies have identified beneficial effects of butyrate against oxidative stress 
and on various components of the intestinal barrier, trefoil peptides and heat shock proteins $[49,50]$, although these effects have still to be confirmed in humans. In addition to colonic barrier defence, butyrate has also been shown to influence the function of immune cells by acting as an agonist (stimulating response) to G-protein-coupled trans-membrane receptors (GPR41 and GPR43) [51] and inhibiting production of proinflammatory cytokines; IL-12 and TNF $\alpha$ following bacterial stimulation [52]. Acetate formed from $3-{ }^{13} \mathrm{C}$ glucose provides an NMR signal for the fermentation pathway of bifidobacteria [53] and, similar to butyrate, has been shown to exhibit anti-inflammatory effects mediated through GPR43 interaction [54]. Furthermore, acetate produced by bifidobacteria has been shown to enhance intestinal protection by enhancing the defence capability of epithelial cells [55].

It has been demonstrated that there is an overall decline in faecal SCFA with age, something that has been correlated with a reduction in bacteroides and bifidobacteria [56]. In view of the immuneenhancing role of SCFA, it maybe speculated that this decrease might contribute towards an adverse effect on immune function. However, diet is also a key modulator of SCFA levels, as when carbohydrates are in abundance in the large intestine, saccharolytic fermentation predominates. When carbohydrate availability is low, especially in more distal colonic regions, protein fermentation occurs, leading to the production of ammonia, hydrogen sulphides, polyamines, indolic and phenolic compounds and branched chain fatty acids (BCFAs), as well as nitric oxide, nitrite and $\mathrm{N}$-nitroso compounds. Metabolites of protein fermentation are generally considered to have adverse effects on the colonic epithelium [57]. Furthermore, a reduction in faecal weight is expected with age (caused by reduced food intake) and these have been linked to a slower intestinal transit time, reduced excretion of bacterial cell mass [58] and increased levels of proteolysis, resulting in the formation of toxic bacterial metabolites [59]. Together, these data suggest processes by which SCFA may impact on host immunity.

In addition to modulations in gut microbial metabolites, age-related changes in immunity linked with metabolite biomarkers have been suggested. In a large-scale metabonomic study where subjects were separated into three distinct age groups (20-35, 50-56, 51-65 years), a number of age-dependent changes were observed, notably increases in the complement components $\mathrm{C} 3, \mathrm{C} 4$ and elevations in allantoin, xanthine, hypoxanthine, inosine, uridine, indicators of high nucleic acid turnover due to inflammation [60]. In a more recent study, a strong positive correlation between IFN- $\gamma$ cytokines and $N$-acetyl glycoproteins was reported (two important pro-inflammatory signalling molecules) in parasite-infected mice. The exact biochemical mechanism behind this correlation needs to be confirmed, however acetyl glycoproteins may be a potential indicator of immunosenescence, as a reduction in IFN-y levels suggest poor NK cell function [61]. Future in-depth analysis is required to further explore direct links between immune function and biochemical pathways during immunosenescence.

\section{Probiotic modulation of immunosenescence}

Research has indicated that the administration of probiotics (live micro-organisms which are beneficial to the health of the host) are able to improve the gut microbial balance leading to prevention of diseases as well as enhanced immunity [62, 63]. Studies have suggested that specific strains of lactic acid producing bacteria may promote immune function as well as simply displaying probiotic abilities [52]. The most well-known probiotics are Lactobacillus and Bifidobacterium, found naturally in the gut and used by the food industry in products such as yoghurts, fermented milks, juices and cheese [64]. Despite their potential benefits, relatively few studies have been carried out looking at the effect of probiotics on the elderly gut microbiota and/or immune status. However, studies have shown that the use of probiotics in human studies is able to promote significant rises in Bifidobacterium and Lactobacillus levels and that the same time significant reductions in more deleterious microorganisms (Table 2). In terms of immune modulation, human and animal trials over the past two decades have demonstrated that there is a notable increase in phagocytic activity and elevated levels of cytokines following probiotic intervention [65]. Specifically, administration of Bifidobacterium lactis HN019 for 6 weeks has been shown to significantly enhance levels of IFN- $\alpha$ and phagocytic capacity of nucleophils in healthy elderly subjects [65]. Furthermore, a commercial probiotic cheese containing Lactobacillus rhamnosus HN001 and Lactobacillus acidophilus NSFM induces an increase in the cytotoxicity of NK cells to kill target tumour cells, as well as 
Table 2

Effect of probiotics on gut microbiota in elderly humans -epidemiological evidence

\begin{tabular}{|c|c|c|c|c|c|}
\hline Study design & Subjects & Age & Probiotic & Result & Author \\
\hline \multirow[t]{2}{*}{$\begin{array}{l}\text { Randomized, } \\
\text { placebo-controlled }\end{array}$} & $n=33($ placebo $)$ & $83 \pm 7 \mathrm{yrs}$ & Fermented oat drink containing $2 \mathrm{C}$ & $\begin{array}{l}\Uparrow \text { B.catenulatum, } \\
\Uparrow \text { B. Bifidum }\end{array}$ & [109] \\
\hline & $n=33$ (probiotic) & $84 \pm 8 \mathrm{yrs}$ & $\begin{array}{l}\text { Bifidobacterium longum } 46 \text { and } \\
\text { B. longum }\end{array}$ & $\Uparrow B$. breve & \\
\hline \multirow[t]{2}{*}{$\begin{array}{l}\text { Randomised, double-blind, } \\
\text { placebo-controlled }\end{array}$} & $n=20($ placebo $)$ & $>60 \mathrm{yrs}$ & $\begin{array}{l}\text { Reconstituted skimmed milk } \\
\text { containing Bifidobacterium lactis } \\
\text { HN019 }\end{array}$ & $\Uparrow$ bifidobacteria & [110] \\
\hline & $\begin{array}{l}n=20(\text { low dose probiotic }) \\
n=20(\text { mediun dose }) \\
n=20(\text { high dose })\end{array}$ & & & $\begin{array}{l}\Uparrow \text { lactobacilli } \\
\Uparrow \text { enterococci } \\
\Downarrow \text { enterobacteria }\end{array}$ & \\
\hline \multirow[t]{2}{*}{$\begin{array}{l}\text { Randomised, double-blind, } \\
\text { placebo-controlled }\end{array}$} & $n=9($ placebo $)$ & 71 yrs (mean) & $\begin{array}{l}\text { Bifidobacterium bifidum BB-02 and } \\
\text { B. lactis BL-01 (probiotics) } \\
\text { together with an inulin-based } \\
\text { prebiotic }\end{array}$ & $\begin{array}{l}\Uparrow \text { bifidobacteria } \\
\Uparrow \text { lactobacilli }\end{array}$ & {$[35]$} \\
\hline & $n=9$ (symbiotic) & 73 yrs (mean) & & $\Downarrow B$. bifidum & \\
\hline
\end{tabular}

improved of phagocytic ability in older volunteers $(>70$ years old) [7]. This supports the findings noted by Gill et al. who reported elevated INF- $\alpha$, lymphocyte counts, circulating counts of $\mathrm{T}$ cells $\left(\mathrm{CD} 4^{+}, \mathrm{CD} 25^{+}\right.$cells) and increased tumoricidal activity of NK cells in elderly subjects consuming milk containing Bifidobacterium lactis HN019 for 9 weeks [66].

Evidence also suggests that the modulation of bacterial metabolite production by both pro and prebiotics may help defend against intestinal oxidative stress and may be mediated by increasing numbers of Clostridium spp. (and therefore butyrate production) in the gut. Increased production of butyrate, has been observed to stimulate glutathione release in the colon and thus improve anti-oxidative capacity [67]. Consumption of probiotic Dahi (yoghurt), produced by co-culturing Lactobacillus acidophilus or combined L. acidophilus and Bifidobacterium bifidum in buffalo milk, led to an increase in glutathione peroxidise in red blood corpuscles and hepatic tissue of ageing mice [68]. In addition, Lactobacillus fermentum $M E-3$ has been found to reduce free radical production via an ability to increase the activity of glutathione reductase, an enzyme responsible for generating reduced glutathione [69]. Furthermore, adults consuming fermented goats' milk containing Lactobacillus fermentum ME-3 were observed to have lower levels of oxidised low density lipoprotein (LDL) compared to individuals consuming a control milk [70], although the validity of this study is questionable due to the low subject number and confirmation of the antioxidant capacity probiotic strains in ageing humans is lacking.
Probiotics have also been used to treat individuals suffering from increased intestinal permeability (or leaky gut syndrome) caused by intestinal disorders [71], for example children with atopic disease and individuals with food allergy or abdominal infection [72] (Table 3). Although not completely established, the manner by which probiotics act to prevent these conditions appears to involve a strengthening the gut mucosal barrier brought about by their ability to promote of the growth of favourable microbiota species that are able to adhere to intestinal mucosa and inhibit pathogen adhesion and growth [73, 74]. In addition, probiotics may enhance intestinal barrier function more directly through their potential to modulate the expression of trans-membrane binding proteins and epithelial tight junction proteins [75, 76] (Fig. 4). Although research in animal models and humans has been explored, the effects of probiotics on leaky gut syndrome in the elderly is limited.

\section{Prebiotic modulation of immunosenescence}

Prebiotics are non-viable food components that may confer health benefits on the host through their ability to promote the growth of a favorable microbiota profile [77]. Prebiotics are naturally available in breast milk and in certain vegetables (in low amounts) but can also be synthetic oligosaccharides, of which the best known and the most researched examples are fructooligosaccharides (FOS) and galactoologosaccharides GOS 
Table 3

The effect of probiotics on subjects suffering from increased intestinal permeability

\begin{tabular}{|c|c|c|c|c|c|}
\hline Study design & Host & Condition & Probiotic & Result & Author \\
\hline $\begin{array}{l}\text { Double-blind, } \\
\text { randomised } \\
\text { placebo-controlled } \\
\text { study }\end{array}$ & $\begin{array}{l}\text { Pre/ postnatal to } \\
\text { children (diagnosed } \\
\text { at } 2 \mathrm{yrs} \text { ) }\end{array}$ & $\begin{array}{l}\text { At risk of developing } \\
\text { atopic disease }\end{array}$ & Lactobacillus GG & $\begin{array}{l}\Downarrow \text { Diagnosis of atopic } \\
\text { disease in probiotic vs. } \\
\text { placebo groups ( } 23 \% \text { vs. } \\
46 \%)\end{array}$ & [111] \\
\hline $\begin{array}{l}3 \text { treatment groups. } \\
\text { Ex vivo tested }\end{array}$ & Rats & Abdominal infection & Lactobacillus plantarum & $\begin{array}{l}\Uparrow \text { Transmembrane } \\
\text { binding proteins } \\
\Uparrow \text { Beneficial flora } \\
\Uparrow \text { Tight junctions } \\
\Downarrow \text { Bacterial translocation }\end{array}$ & {$[112]$} \\
\hline $\begin{array}{l}\text { Double-blind, } \\
\text { randomised } \\
\text { placebo-controlled } \\
\text { study }\end{array}$ & $\begin{array}{l}\text { Children (mean } \\
\text { age }=2.4 \text { months) }\end{array}$ & $\begin{array}{l}\text { At risk of developing } \\
\text { cows milk allergy }\end{array}$ & Lactobacillus GG & $\Downarrow$ Intestinal inflammation & [113] \\
\hline $\begin{array}{l}\text { Placebo controlled } \\
\text { treatment groups. } \\
\text { Ex vivo tested }\end{array}$ & Rats & $\begin{array}{l}\text { Radiation induced } \\
\text { intestinal injury }\end{array}$ & Lactobacillus bulgaricus & $\begin{array}{l}\Uparrow \text { Bowel mucosal mass } \\
\Downarrow \text { Bacterial translocation } \\
\Downarrow \text { Intestinal pathogens }\end{array}$ & {$[114]$} \\
\hline
\end{tabular}

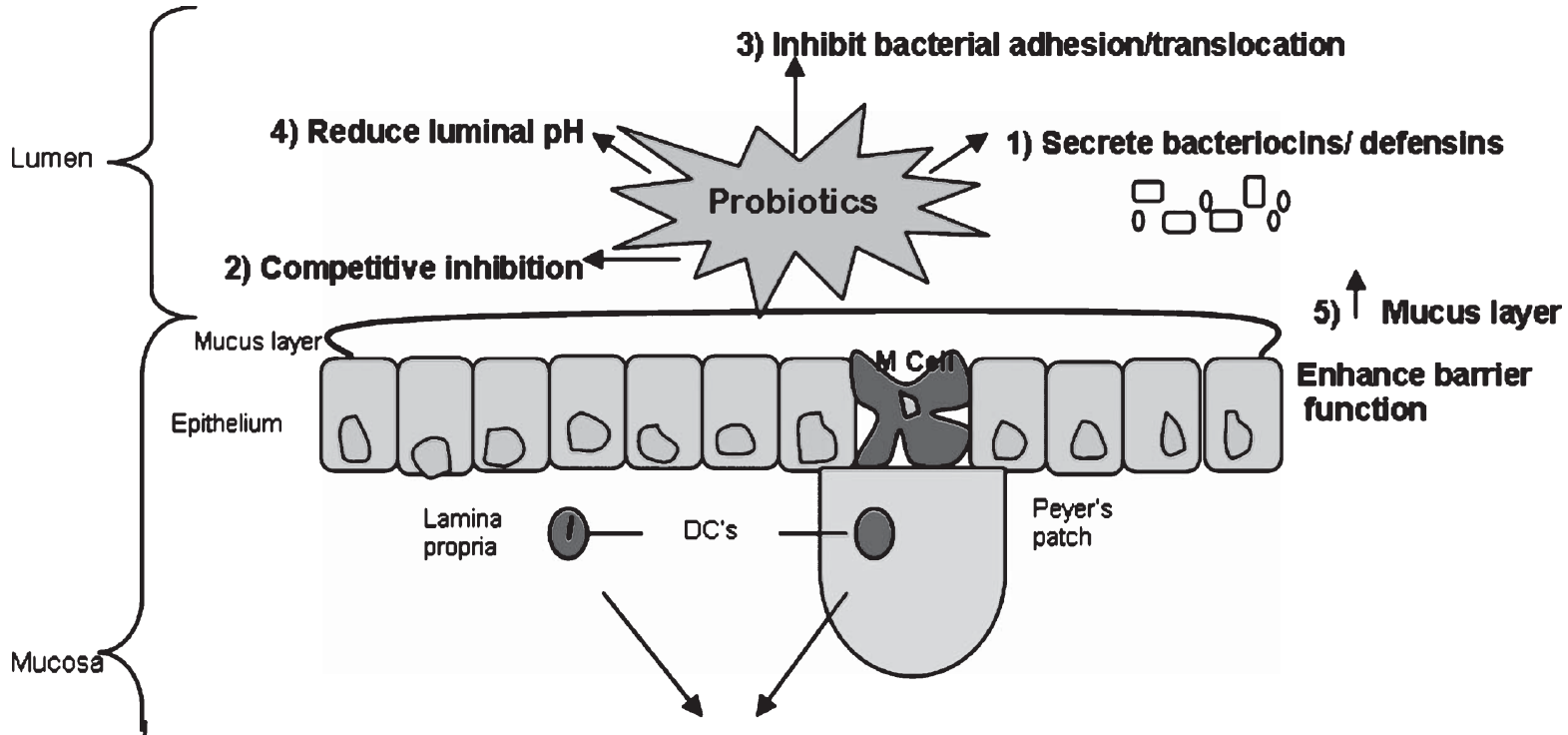

Mesenteric kymph nodes

Fig. 4. Inhibition of enteric bacteria and enhancement of barrier function by probiotic bacteria. Schematic representation of the crosstalk between probiotic bacteria and the intestinal mucosa.by (1) production of bacteriocins/defensins, (2) competitive inhibition with pathogenic bacteria, [100] inhibition of bacterial adherence or translocation (4) reduction of luminal pH (5) Enhance epithelial and mucosal barrier function. Adapted from [75].

$[78,79]$. As with probiotics, few studies have focussed on the influence of prebiotics on the microbiota in elderly individuals, although current evidence has indicated distinct and consistent increases in bifidobacteria and decreases in pathogenic bacteria following their intake (Table 4). Indeed, there is good evidence to suggest that prebiotics support the growth of potentially beneficial bacteria (bifidobacteria and lactobacilli) in humans, although their effects on the immune system originate primarily from animal studies [80]. For example, consumption of FOS by mice has been shown to lead to the increased phagocytic capacity of macrophages promoting their potential to destroy foreign microorganisms [81]. This may be mediated by a 
Table 4

Effect of prebiotics on gut microbiota in elderly humans - epidemiological evidence

\begin{tabular}{|c|c|c|c|c|c|c|}
\hline Study design & Subjects & Age & Prebiotic & Dose & Result & Author \\
\hline $\begin{array}{l}\text { Randomised } \\
\text { double-blind, parallel } \\
\text { study }\end{array}$ & $n=10$ & 76.4 yrs (mean) & Chicory insulin & $\begin{array}{l}20 \text { g/day (Days 1-8) } \\
40 \text { g/day (Days } \\
12-19 \text { ) }\end{array}$ & $\begin{array}{l}\Uparrow \text { bifidobacteria, } \\
\Downarrow \text { enterobacteria } \\
\Downarrow \text { enterococci }\end{array}$ & {$[115]$} \\
\hline Single treatment study & $n=19$ & $85 \pm 6$ yrs & FOS powder & $8 \mathrm{~g} /$ day & $\Uparrow$ bifidobacteria & {$[82]$} \\
\hline Single treatment study & $n=12$ & $69 \pm 2$ yrs & FOS powder & $8 \mathrm{~g} /$ day & 介 bifidobacteria & [116] \\
\hline $\begin{array}{l}\text { Randomised } \\
\text { double-blind, } \\
\text { placebo-controlled, } \\
\text { crossover study }\end{array}$ & $n=44$ & $69.3 \pm 4.0 \mathrm{yrs}$ & $\begin{array}{l}\text { GOS mixture } \\
\text { (B-GOS; Bi2muno) }\end{array}$ & $5.5 \mathrm{~g} /$ day & $\begin{array}{l}\Uparrow \text { bifidobacteria } \\
\Uparrow \text { Lactobacillus- } \\
\text { Enterococcus } \mathrm{spp} \text {. } \\
\Uparrow \text { C. coccoides }- \text { E. } \\
\text { rectale group } \\
\Downarrow c . \text { histolyticum group } \\
\Downarrow E . \text { coli } \\
\Downarrow \text { Desulfovibrio } \mathrm{spp} \text {. }\end{array}$ & [83] \\
\hline $\begin{array}{l}\text { Randomised double- } \\
\text { blind, placebo } \\
\text { controlled, crossover } \\
\text { study }\end{array}$ & $n=37$ & $>50 \mathrm{yrs}$ & GOS in juice & $4 \mathrm{~g} /$ day & $\begin{array}{l}\Uparrow \text { bifidobacteria } \\
\Uparrow \text { butyrate no change in } \\
\text { fecal water genotoxicity }\end{array}$ & [117] \\
\hline
\end{tabular}

mechanism involving increased secretion of intestinal immunoglobulin A (IgA), thus promoting the binding and transport of pathogens out through the gut epithelium and into the lumen (blood vessel). The observed increase in IFN- $\gamma$ suggests that NK cell and T helper cell functions were enhanced, whilst increased levels of IL-10 in Peyer's patches suggest an additional antiinflammatory response. In contrast, Guigoz et al., [82] noted a reduced phagocytic activity of polymorphs and monocytes in animal models. The expression of pro-inflammatory cytokine IL-6 mRNA in peripheral blood mononuclear cells (PBMCs) decreased however, supporting previous findings. These observations attributed to a general decrease in inflammation. Some data for the immune effects of FOS in elderly individuals exists, for example where individuals aged 77-90 years received $8 \mathrm{~g}$ of FOS daily for three weeks and experienced increased bifidobacterial levels and significant rises in total lymphocyte count $\left(\mathrm{CD}^{4+}\right.$ and $\mathrm{CD}^{8+}$ cells).

The immune enhancing effects of GOS in the elderly are less documented than FOS. Indeed, only one recent trial has investigated the effects of GOS on immune function in the elderly (65-80 years old), where a prebiotic mixture (B-GOS) was observed to increase levels of bifidobacteria and to increase phagocytosis, NK cell activity and IL-10 cytokines, whilst reducing the pro-inflammatory cytokines (IL-6, IL- $1 ß$ and TNF$\alpha)$ [83]. Bearing in mind the intestinal permeability of prebiotics, it seems likely that they function via the same mode of action as probiotics in reducing bacterial translocation, maintaining a positive gut microbiota community [84] and enhancing the gut mucosal barrier. In support of the latter, it has been demonstrated that altering the gut microbiota in genetically obese mice with prebiotic oligofructose leads to a significant improvement in gut permeability and an increase in tight junction protein expression [85]. Furthermore, oligofructose and inulin has been shown to increase villus height, crypt depth and increase the thickness of the mucosal layer in the jejunum and colon of rats [86]. Although the evidence from animal model investigations is compelling, the effect of prebiotics on increased gut permeability in humans remains to be elucidated.

Another line of evidence, which suggests that prebiotics may enhance immune function, stems from metabonomic studies that have focused on microbialhost metabolic interactions. Metabolites, generated by the gut microbiota are to known to have various effects on the host immune system (Fig. 5) [48]. Studies have shown that FOS, GOS and inulin have a prebiotic effect by maintaining lactate and acetate production (primarily by Bifidobacterium spp.) which inhibit the growth of potential pathogens $[87,88]$. In additon, the fermentation of GOS by Clostridium spp. results in the production of butyrate which serves as a fuel for colonic epithelial cells [89] as well as the production of propionate (via Bacteroides spp. fermentation), which has been shown to be anti-inflammatory [90]. GOS ingestion ( $15 \mathrm{~g} /$ day) has also been shown to decrease levels of toxic SCFA, notably valerate, isovalerate and 


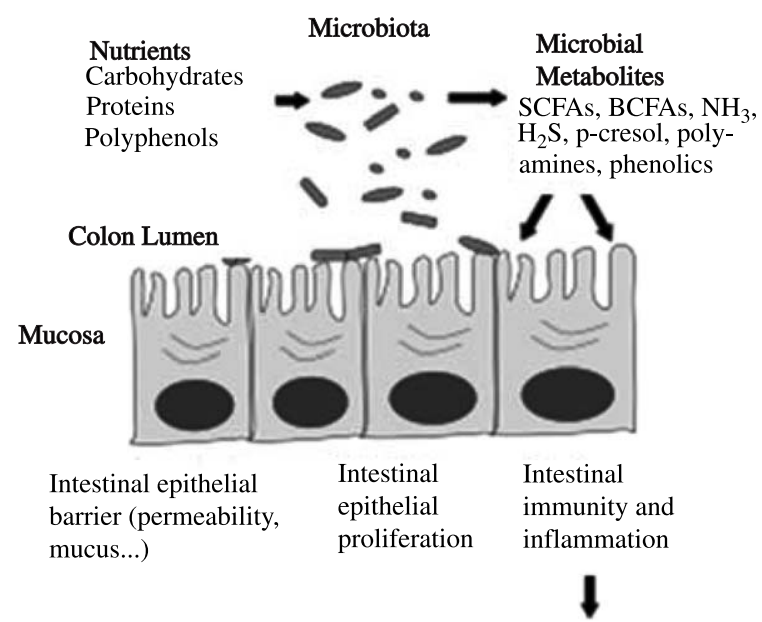

Systemic immunity and AOX potential

Fig. 5. The potential impact of non-digestible food ingredients on the gut and immune function through the production of microbial metabolites [48] (image kindly permitted by Dr Doris Jacobs, Unilever R\&D, Vlaardingen, The Netherlands).

isobutyrate [91], although another study found that ingestion of GOS ( $7.5 \mathrm{~g} /$ day or $15 \mathrm{~g} /$ day for a 3 weeks) had minimal effect faecal microbial metabolites [92]. As previously mentioned the increase in butyrate production via Clostridium spp. stimulates the release of glutathione (an anti-oxidant). Several prebiotic studies have reported this effect (Table 5) however further investigation is needed to confirm this mechanism in humans.

B-GOS is produced synthetically through the action of B-galactosidases on lactose, with different mixtures produced depending on the source of the ß-galactosidase enzyme [93]. Using enzymes that originate in probiotic organisms to produce a GOS mixture, should result in a higher selectivity towards these specific strains of bacteria [94]. In addition, the conversion of lactose into GOS can be controlled (by temperature, $\mathrm{pH}$, substrate concentration and enzyme activity) such that the rate of polymerisation of GOS matches physiological preferences of the target microorganisms (in this case, Bifidobacterium spp.) [95]. This approach has led to the production of a novel low molecular weight GOS mixture ( $\mathrm{Bi}^{2}$ muno; B-GOS) developed using enzymes from the probiotic strain Bifidobacterium bifidum NCIMB 41171 [96]. Recent data suggest that B-GOS enhances immune responses in the elderly by increasing numbers of indigenous probiotic bacteria, especially bifidobacteria, and the subsequent production of SCFA through GOS fermentation [83]. These data are supported by in vitro data which indicate that B-GOS significantly decreases TNF- $\alpha$ stimulated IL-8 and macrophage inflammatory protein $-3 \alpha$ (MIP-3 $\alpha$ ) production [97]. Furthermore, B-GOS significantly decreases the attachment of enteropathogenic E. coli (EPEC) and Salmonella enterica serovar Typhimurium to colonic cells in vitro, suggesting that in the presence of B-GOS the ability of these pathogens to act on the gut epithelium is reduced [98]. Although, further data are required, these findings hint at the potential of B-GOS to reduce inflammation through both direct and indirect mechanisms.

In summary, the data in this section together suggest that pro and prebiotics may be capable of inducing favourable effects on immune function via three routes (Fig. 6): (i) by promoting the growth of beneficial bacteria, leading to inhibition of pathogenic bacterial

Table 5

Effect of prebiotics on oxidative stress

\begin{tabular}{|c|c|c|c|c|}
\hline Study design & Subject type & Prebiotic & Result & Author \\
\hline In vivo treatment versus control & Rat plasma & $\begin{array}{l}\text { Feruloyl oligosaccharide } \\
\text { (a putative prebiotic) }\end{array}$ & $\begin{array}{l}\Uparrow \text { Superoxide dismutase, catalase } \\
\text { and glutathione peroxidase (anti- } \\
\text { oxidant enzymes) }\end{array}$ & [118] \\
\hline In vitro study & Human cells & Chitin oligosaccharides & $\Uparrow$ Glutathione (anti-oxidant) & [119] \\
\hline $\begin{array}{l}\text { Placebo controlled, randomised } \\
\text { parallel study }\end{array}$ & Male humans & Insulin & $\begin{array}{l}\Uparrow \text { Antioxidant potential (ferric } \\
\text { reducing ability) }\end{array}$ & [120] \\
\hline $\begin{array}{l}\text { Placebo controlled, diet controlled } \\
\text { study }\end{array}$ & Elderly humans & FOS & $\begin{array}{l}\Downarrow \text { Thiobarbituric acid-reactive } \\
\text { substances (TBARS) (biochemical } \\
\text { markers of oxidative stress) }\end{array}$ & [121] \\
\hline $\begin{array}{l}\text { In vivo treatment groups versus } \\
\text { control }\end{array}$ & Neonatal Rats & GOS/FOS & $\begin{array}{l}\Uparrow \text { Superoxide dismutase, catalase } \\
\text { and glutathione peroxidase (anti } \\
\text { oxidant enzymes) }\end{array}$ & [122] \\
\hline
\end{tabular}




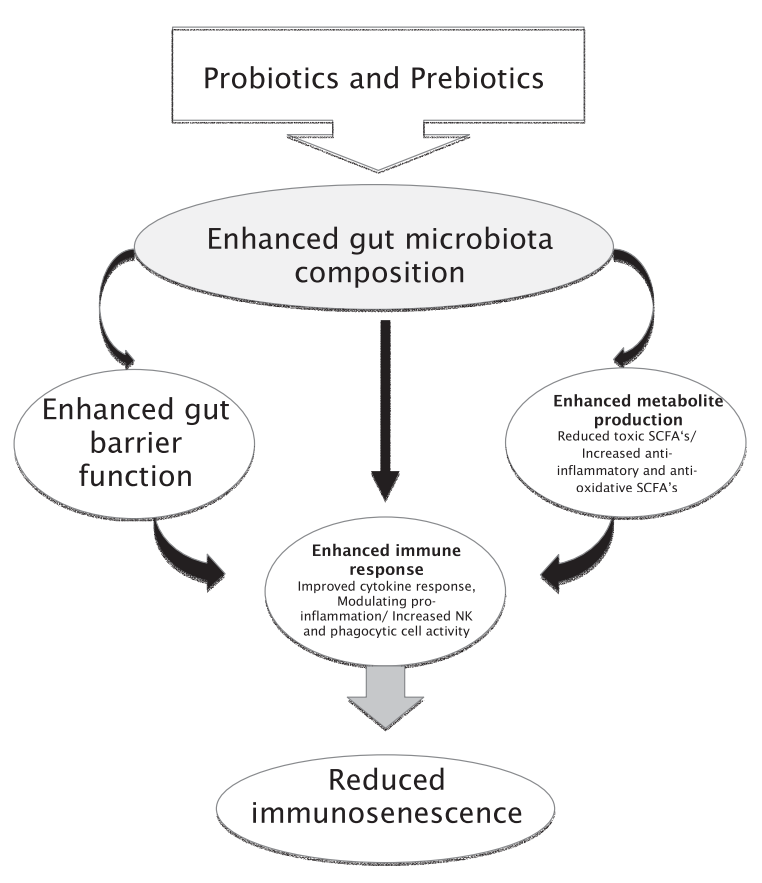

Fig. 6. The biological effects of pro and prebiotics on immunosenescence.

growth; (ii) by increasing the production of antiinflammatory SCFAs and/or inhibiting the production of toxic SCFAs, which promote inflammation; and (iii) by enhancing the integrity of the gut mucosal barrier, thus inhibiting pathogen invasion. Other mechanisms are also being proposed, which also may positively affect immune system functioning: a) an enhancement of inflammatory mechanisms in response to foreign body invasion through the elevation of levels of $\operatorname{IgA}$, lymphocyte counts, cytokines, phagocytic cell and NK cell activity; (b) a reduction in the stimulation of proinflammatory cytokines (IL-6, IL-1B, TNF- $\alpha$ ); (c) a counteraction of chronic inflammation through the increased production of IL-10 and propionate and; (d) a reduction in oxidative stress via the stimulation of glutathione release by butyrate. These latter pathways are interesting but require further investigation in order for them to be fully elucidated.

\section{Conclusions and future directions}

To date, the known health effects of probiotics, and to a lessor extent prebiotics, in the elderly is limited, particularly with respect to immune regulation. Of the prebiotic studies carried out to date, FOS and inulin have provided the majority of the data, with recent evidence suggesting GOS may also have the potential to impact on immune function and thus delay immunosenescence. Research to date has focussed strongly on modulation of bacterial groups and species in the large intestine by prebiotics and the formation of small moleculr metabolites that may influence host health and disease. However, future work will require a better understanding of the measurement of immune parameters, and will need to utilise metabonomics to fully explore the functional impact of diet induced changes on the immune system and wider metabolism in healthy and/or at risk populations. In this regard, current and planned studies have a much greater focus on using metabonomics to identify a broader array of potential biomarkers relevant to immunosenescence. Furthermore, they aim to gain a greater understanding of microbe-induced metabolic effects in the host and potential immune modulations prior to and following prebiotic interventions. If successful, these new metabolic and immune markers may be employed as indicators of the immune-boosting potential of prebiotics.

\section{Acknowledgments}

The authors are sponsored by Clasado limited.

\section{References}

[1] Pawelec G, Gouttefangeas C. T-cell dysregulation caused by chronic antigenic stress: The role of CMV in immunosenescence? Aging Clinical and Experimental Research. 2006;18(2):171-3.

[2] Bloom DE, Borsch-Supan A, McGee P, Seike A. Population Ageing: Macro Challenges and Policy Responses. Global Population Ageing: Peril or Promise? 2012;35:1-148.

[3] Pench L, Gudin De Vallerin P, Part P, Carone G. The 2012 Ageing Report - Economic and budgetary projections for the 27 EU Member States (2010-2060). The European Economy series. 2012;1(2):25:7.

[4] Castle SC. Clinical relevance of age-related immune dysfunction. Clinical infectious diseases. 2000;31(2):578-85.

[5] Tarazona R, Solana R, Ouyang Q, Pawelec G. Basic biology and clinical impact of immunosenescence. Experimental gerontology. 2002;37(2):183-9.

[6] Gomez CR, Boehmer ED, Kovacs EJ. The aging innate immune system. Current Opinion in Immunology. 2005;17(5):457-62.

[7] Ibrahim F, Ruvio S, Granlund L, Salminen S, Viitanen M, Ouwehand AC. Probiotics and immunosenescence: Cheese 
as a carrier. FEMS Immunology and Medical Microbiology. 2010;59(1):53-9.

[8] Lang P, Mitchell W, Lapenna A, Pitts D, Aspinall R. Immunological pathogenesis of main age-related diseases and frailty: Role of immunosenescence. European Geriatric Medicine. 2010;1(2):112-21.

[9] Weng NP. Aging of the immune system: How much can the adaptive immune system adapt? Immunity. 2006;24(5): 495-9.

[10] DeVeale B, Brummel T, Seroude L. Immunity and aging: The enemy within? Aging Cell. 2004;3(4):195-208.

[11] Mishto M, Santoro A, Bellavista E, BonafÈ M, Monti D, Franceschi C. Immunoproteasomes and immunosenescence. Ageing Research Reviews. 2003;2(4):419-32.

[12] Ershler WB, Keller ET. Age-associated increased interleukin6 gene expression, late-life diseases, and frailty. Annual Review of Medicine. 2000;51:245-70.

[13] Harris TB, Ferrucci L, Tracy RP, Corti MC, Wacholder S, Ettinger WH, Jr., et al. Associations of elevated interleukin-6 and C-reactive protein levels with mortality in the elderly. American Journal of Medicine. 1999;106(5):506-12.

[14] Striz I, Trebichavsky I. Calprotectin - a pleiotropic molecule in acute and chronic inflammation. Physiological Research. 2004;53(3):245-53.

[15] Poullis A, Foster R, Shetty A, Fagerhol MK, Mendall MA. Bowel inflammation as measured by fecal calprotectin. Cancer Epidemiology Biomarkers \& Prevention. 2004;13(2):279-84.

[16] Nuttall S, Martin U, Sinclair A, Kendall M. Glutathione: In sickness and in health. Lancet. 1998;351(9103):645.

[17] Harman D. The aging process. Proceedings of the National Academy of Sciences. 1981;78(11):7124.

[18] Kregel KC, Zhang HJ. An integrated view of oxidative stress in aging: Basic mechanisms, functional effects, and pathological considerations. American Journal of Physiology-Regulatory, Integrative and Comparative Physiology. 2007;292(1):R18-R36.

[19] Geissler CA, Bates JF. The nutritional effects of tooth loss. The American Journal of Clinical Nutrition. 1984;39(3): 478-89.

[20] Westenhoefer J, Elmadfa I, editors. Age and gender dependent profile of food choice. Diet Diversification and Health Promotion Forum of Nutrition Karger; 2005.

[21] Kuipers E. Helicobacter pylori and the risk and management of associated diseases: Gastritis, ulcer disease, atrophic gastritis and gastric cancer. Alimentary Pharmacology \& Therapeutics. 1997;11(S1):71-88.

[22] Russell RM. Changes in gastrointestinal function attributed to aging. The American Journal of Clinical Nutrition. 1992;55(6 Suppl):1203S-7S.

[23] Madsen JL, Graff J. Effects of ageing on gastrointestinal motor function. Age and Ageing. 2004;33(2):154-9.

[24] Lipski E. Leaky gut syndrome. Keats Publishing; 1998.

[25] Albright JF, Albright JW. Aging, Immunity, and Infection. Humana Press Inc; 2003.

[26] Qin J, Li R, Raes J, Arumugam M, Burgdorf KS, Manichanh $\mathrm{C}$, et al. A human gut microbial gene catalogue established by metagenomic sequencing. Nature. 2010;464(7285):59-65.

[27] O'Hara AM, Shanahan F. The gut flora as a forgotten organ. EMBO reports. 2006;7(7):688-93.
[28] Mitsuoka T. Bifidobacteria and their role in human health. Journal of Industrial Microbiology \& Biotechnology. 1990;6(4):263-7.

[29] Woodmansey EJ, McMurdo MET, Macfarlane GT, Macfarlane S. Comparison of compositions and metabolic activities of fecal microbiotas in young adults and in antibiotictreated and non-antibiotic-treated elderly subjects. Applied and Environmental Microbiology. 2004;70(10):6113-22.

[30] Rajilic-Stojanovic M, Heilig HGHJ, Molenaar D, Kajander K, Surakka A, Smidt H, et al. Development and application of the human intestinal tract chip, a phylogenetic microarray: Analysis of universally conserved phylotypes in the abundant microbiota of young and elderly adults. Environmental Microbiology. 2009;11(7):1736-51.

[31] Mueller S, Saunier K, Hanisch C, Norin E, Alm L, Midtvedt $\mathrm{T}$, et al. Differences in fecal microbiota in different European study populations in relation to age, gender, and country: A cross-sectional study. Applied and Environmental Microbiology. 2006;72(2):1027-33.

[32] Hayashi H, Sakamoto M, Kitahara M, Benno Y. Molecular analysis of fecal microbiota in elderly individuals using $16 \mathrm{~S}$ rDNA library and T-RFLP. Microbiology and Immunology. 2003;47(8):557.

[33] Biagi E, Nylund L, Candela M, Ostan R, Bucci L, Pini E, et al. Through ageing, and beyond: Gut microbiota and inflammatory status in seniors and centenarians. PLoS One. 2010;5(5):e10667.

[34] Makivuokko H, Tiihonen K, Tynkkynen S, Paulin L, Rautonen $\mathrm{N}$. The effect of age and non-steroidal anti-inflammatory drugs on human intestinal microbiota composition. British Journal of Nutrition. 2010;103(2):227.

[35] Bartosch S, Fite A, Macfarlane GT, McMurdo MET. Characterization of bacterial communities in feces from healthy elderly volunteers and hospitalized elderly patients by using real-time PCR and effects of antibiotic treatment on the fecal microbiota. Applied and Environmental Microbiology. 2004;70(6):3575.

[36] Claesson MJ, Jeffery IB, Conde S, Power SE, O'Connor EM, Cusack S, et al. Gut microbiota composition correlates with diet and health in the elderly. Nature. 2012;488(7410):17884.

[37] Mallett A, Bearne C, Rowland I, Farthing M, Cole C, Fuller R. The use of rats associated with a human faecal flora as a model for studying the effects of diet on the human gut microflora. Journal of Applied Microbiology. 1987;63(1):39-45.

[38] Goldin BR. Intestinal microflora: Metabolism of drugs and carcinogens. Annals of Medicine. 1990;22(1):43-8.

[39] Biagi E, Candela M, Fairweather-Tait S, Franceschi C, Brigidi P. Ageing of the human metaorganism: The microbial counterpart. Age. 2012;34(1):247-67.

[40] Franceschi C, Capri M, Monti D, Giunta S, Olivieri F, Sevini $\mathrm{F}$, et al. Inflammaging and anti-inflammaging: A systemic perspective on aging and longevity emerged from studies in humans. Mechanisms of Ageing and Development. 2007;128(1):92-105.

[41] Tien MT, Girardin SE, Regnault B, Le Bourhis L, Dillies MA, Coppee JY, et al. Anti-inflammatory effect of Lactobacillus casei on Shigella-infected human intestinal epithelial cells. The Journal of Immunology. 2006;176(2):1228-37. 
[42] Sokol H, Pigneur B, Watterlot L, Lakhdari O, BermudezHumaran LG, Gratadoux JJ, et al. Faecalibacterium prausnitzii is an anti-inflammatory commensal bacterium identified by gut microbiota analysis of Crohn disease patients. Proceedings of the National Academy of Sciences. 2008;105(43): 16731.

[43] Heuvelin E, Lebreton C, Grangette C, Pot B, Cerf-Bensussan $\mathrm{N}$, Heyman M. Mechanisms involved in alleviation of intestinal inflammation by Bifidobacterium breve soluble factors. PLoS One. 2009;4(4):e5184.

[44] Van Baarlen P, Troost FJ, Van Hemert S, Van Der Meer C, De Vos WM, De Groot PJ, et al. Differential NF-kB pathways induction by Lactobacillus plantarum in the duodenum of healthy humans correlating with immune tolerance. Proceedings of the National Academy of Sciences. 2009;106(7): 2371.

[45] Kelly D, Campbell JI, King TP, Grant G, Jansson EA, Coutts AGP, et al. Commensal anaerobic gut bacteria attenuate inflammation by regulating nuclear-cytoplasmic shuttling of PPAR-y and RelA. Nature Immunology. 2003;5(1):104-12.

[46] Gibney M, Walsh M, Brennan L, Roche H, German B, van Ommen B. Metabolomics in human nutrition: Opportunities and challenges. American Journal of Clinical Nutrition. 2005;82(3):497.

[47] Holmes E, Wilson ID, Nicholson JK. Metabolic phenotyping in health and disease. Cell. 2008;134(5):714-7.

[48] Jacobs D, Gaudier E, Duynhoven J, Vaughan E. Nondigestible food ingredients, colonic microbiota and the impact on gut health and immunity: A role for metabolomics. Current Drug Metabolism. 2009;10(1):41-54.

[49] Hamer HM, Jonkers D, Venema K, Vanhoutvin S, Troost F, Brummer RJ. Review article: The role of butyrate on colonic function. Alimentary Pharmacology \& Therapeutics. 2008;27(2):104-19.

[50] Wong JMW, De Souza R, Kendall CWC, Emam A, Jenkins DJA. Colonic health: Fermentation and short chain fatty acids. Journal of Clinical Gastroenterology. 2006;40(3):235.

[51] Gupta N, Martin PM, Prasad PD, Ganapathy V. SLC5A8 (SMCT1)-mediated transport of butyrate forms the basis for the tumor suppressive function of the transporter. Life Sciences. 2006;78(21):2419-25.

[52] Saemann MD, Bohmig GA, Osterreicher CH, Burtscher H, Parolini O, Diakos C, et al. Anti-inflammatory effects of sodium butyrate on human monocytes: Potent inhibition of IL-12 and up-regulation of IL-10 production. The Federation of American Societies for Experimental Biology Journal. 2000;14(15):2380.

[53] Wolin MJ, Zhang Y, Bank S, Yerry S, Miller TL. NMR detection of $13 \mathrm{CH} 313 \mathrm{COOH}$ from 3-13C-glucose: A signature for Bifidobacterium fermentation in the intestinal tract. Journal of Nutrition. 1998;128(1):91-6.

[54] Maslowski KM, Vieira AT, Ng A, Kranich J, Sierro F, $\mathrm{Yu} \mathrm{D}$, et al. Regulation of inflammatory responses by gut microbiota and chemoattractant receptor GPR43. Nature. 2009; 461(7268):1282-6.

[55] Fukuda S, Toh H, Hase K, Oshima K, Nakanishi Y, Yoshimura $\mathrm{K}$, et al. Bifidobacteria can protect from enteropathogenic infection through production of acetate. Nature. 2011;469(7331):543-7.
[56] Woodmansey E. Intestinal bacteria and ageing. Journal of Applied Microbiology. 2007;102(5):1178-86.

[57] Blachier F, Mariotti F, Huneau J, Tome D. Effects of amino acid-derived luminal metabolites on the colonic epithelium and physiopathological consequences. Amino Acids. 2007;33(4):547-62.

[58] Stephen AM, Wiggins H, Cummings J. Effect of changing transit time on colonic microbial metabolism in man. Gut. 1987;28(5):601-9.

[59] Macfarlane G, Cummings J, Macfarlane S, Gibson G. Influence of retention time on degradation of pancreatic enzymes by human colonic bacteria grown in a 3-stage continuous culture system. Journal of Applied Microbiology. 1989;67(5):521-7.

[60] Lawton KA, Berger A, Mitchell M, Milgram KE, Evans AM, Guo L, et al. Analysis of the adult human plasma metabolome. Pharmacogenomics. 2008;9(4):383-97.

[61] Saric J, Li JV, Swann JR, Utzinger J, Calvert G, Nicholson $\mathrm{JK}$, et al. Integrated cytokine and metabolic analysis of pathological responses to parasite exposure in rodents. Journal of Proteome Research. 2010;9(5):2255-64.

[62] Reid G, Jass J, Sebulsky MT, McCormick JK. Potential uses of probiotics in clinical practice. Clinical Microbiology Reviews. 2003;16(4):658-72.

[63] Borchers AT, Selmi C, Meyers FJ, Keen CL, Gershwin ME. Probiotics and immunity. Journal of gastroenterology. 2009;44(1):26-46.

[64] Fuller R, Gibson G. Modification of the intestinal microflora using probiotics and prebiotics. Scandinavian Journal of Gastroenterology Supplement. 1997;222:28.

[65] Arunachalam K, Gill HS, Chandra RK. Enhancement of natural immune function by dietary consumption of Bifidobacterium lactis (HN019). European Journal of Clinical Nutrition. 2000;54(3):263-7.

[66] Gill HS, Rutherfurd KJ, Cross ML, Gopal PK. Enhancement of immunity in the elderly by dietary supplementation with the probiotic Bifidobacterium lactis HN019. The American Journal of Clinical Nutrition. 2001;74(6):833.

[67] Wollowski I, Rechkemmer G, Pool-Zobel BL. Protective role of probiotics and prebiotics in colon cancer. The American Journal of Clinical Nutrition. 2001;73(2): $451 \mathrm{~S}$.

[68] Kaushal D, Kansal V. Probiotic Dahi containing Lactobacillus acidophilus and Bifidobacterium bifidum alleviates age-inflicted oxidative stress and improves expression of biomarkers of ageing in mice. Molecular Biology Reports. 2011;39(2):1791-9.

[69] Kullisaar T, Zilmer M, Mikelsaar M, Vihalemm T, Annuk $\mathrm{H}$, Kairane C, et al. Two antioxidative lactobacilli strains as promising probiotics. International Journal of Food Microbiology. 2002;72(3):215-24.

[70] Kullisaar T, Songisepp E, Mikelsaar M, Zilmer K, Vihalemm T, Zilmer M. Antioxidative probiotic fermented goats' milk decreases oxidative stress-mediated atherogenicity in human subjects. British Journal of Nutrition. 2003;90(2):44956.

[71] Isolauri E, Sütas Y, Kankaanpää P, Arvilommi H, Salminen S. Probiotics: Effects on immunity. The American journal of clinical nutrition. 2001;73(2):444s-50s. 
[72] Salminen S, Isolauri E, Salminen E. Clinical uses of probiotics for stabilizing the gut mucosal barrier: Successful strains and future challenges. Antonie Van Leeuwenhoek. 1996;70(2):347-58.

[73] Wehkamp J, Harder J, Wehkamp K, Meissner BW, Schlee $\mathrm{M}$, Enders C, et al. NF-kappa B-and AP-1-mediated induction of human beta defensin-2 in intestinal epithelial cells by Escherichia coli Nissle 1917: A novel effect of a probiotic bacterium. Infection and Immunity. 2004;72(10): 5750.

[74] Malchow HA. Crohn's disease and Escherichia coli: A new approach in therapy to maintain remission of colonic Crohn's disease? Journal of Clinical Gastroenterology. 1997;25(4):653.

[75] Ng S, Hart A, Kamm M, Stagg A, Knight S. Mechanisms of action of probiotics: Recent advances. Inflammatory Bowel Diseases. 2009;15(2):300-10.

[76] Otte JM, Podolsky DK. Functional modulation of enterocytes by gram-positive and gram-negative microorganisms. American Journal of Physiology-Gastrointestinal and Liver Physiology. 2004;286(4):G613.

[77] Gibson GR, Scott KP, Rastall RA, Tuohy KM, Hotchkiss A, Dubert-Ferrandon A, et al. Dietary prebiotics: Current status and new definition. Food Science \& Technology Bulletin: Functional Foods. 2010;7(1):1-19.

[78] Gosling A, Alftren J, Stevens GW, Barber AR, Kentish SE, Gras SL. Facile pretreatment of Bacillus circulans beta-galactosidase increases the yield of galactosyl oligosaccharides in milk and lactose reaction systems. Journal of Agriculture and Food Chemistry. 2009 Dec 23;57(24):11570-4.

[79] Rastall RA, Maitin V. Prebiotics and synbiotics: Towards the next generation. Current Opinion in Biotechnology. 2002 Oct;13(5):490-6.

[80] Kelly-Quagliana K, Nelson P, Buddington R. Dietary oligofructose and inulin modulate immune functions in mice. Nutrition Research. 2003;23(2):257-67.

[81] Hosono A, Ozawa A, Kato R, Ohnishi Y, Nakanishi Y, Kimura $\mathrm{T}$, et al. Dietary fructooligosaccharides induce immunoregulation of intestinal IgA secretion by murine Peyer's patch cells. Bioscience, Biotechnology, and Biochemistry. 2003;67(4):758-64.

[82] Guigoz Y, Rochat F, Perruisseau-Carrier G, Rochat I, Schiffrin E. Effects of oligosaccharide on the faecal flora and non-specific immune system in elderly people. Nutrition Research. 2002;22(1-2):13-25.

[83] Vulevic J, Drakoularakou A, Yaqoob P, Tzortzis G, Gibson GR. Modulation of the fecal microflora profile and immune function by a novel trans-galactooligosaccharide mixture (BGOS) in healthy elderly volunteers. The American Journal of Clinical Nutrition. 2008;88(5):1438-46.

[84] Ozcelik M, Eroglu C, Pekmezci S, Oeztuerk R, Paksoy M, Negizade M, et al. The role of lactulose in the prevention of bacterial translocation in surgical trauma. Acta Chirurgica Belgica. 1996(1):44-8.

[85] Cani PD, Possemiers S, Van de Wiele T, Guiot Y, Everard A, Rottier O, et al. Changes in gut microbiota control inflammation in obese mice through a mechanism involving GLP-2-driven improvement of gut permeability. Gut. 2009;58(8):1091.
[86] Kleessen B, Hartmann L, Blaut M. Fructans in the diet cause alterations of intestinal mucosal architecture, released mucins and mucosa-associated bifidobacteria in gnotobiotic rats. British Journal of Nutrition. 2003;89(5):597-606.

[87] Pharmaceutiques UL. Dietary modulation of the human colonie microbiota: Introducing the concept of prebiotics. 1995.

[88] Kajiwara S, Gandhi H, Ustunol Z. Effect of honey on the growth of and acid production by human intestinal Bifidobacterium spp.: An in vitro comparison with commercial oligosaccharides and inulin. Journal of Food Protection 2002;65(1):214-8.

[89] Hopkins MJ, Macfarlane GT. Nondigestible oligosaccharides enhance bacterial colonization resistance against Clostridium difficile in vitro. Applied and Environmental Microbiology. 2003;69(4):1920-7.

[90] Nurmi JT, Puolakkainen PA, Rautonen NE. Bifidobacterium Lactis sp. 420 up-regulates cyclooxygenase (Cox)-1 and down-regulates Cox-2 gene expression in a Caco-2 cell culture model. Nutrition and Cancer. 2005;51(1):83-92.

[91] Ito M, Kimura M, Deguchi Y, Miyamori-Watabe A, Yajima T, Kan T. Effects of transgalactosylated disaccharides on the human intestinal microflora and their metabolism. Journal of Nutritional Science and Vitaminology. 1993;39(3):279.

[92] Alles MS, Hartemink R, Meyboom S, Harryvan JL, Van Laere KMJ, Nagengast FM, et al. Effect of transgalactooligosaccharides on the composition of the human intestinal microflora and on putative risk markers for colon cancer. The American Journal of Clinical Nutrition. 1999;69(5):980-91.

[93] Depeint F, Tzortzis G, Vulevic J, I'Anson K, Gibson G. Prebiotic evaluation of a novel galactooligosaccharide mixture produced by the enzymatic activity of Bifidobacterium bifidum NCIMB 41171, in healthy humans: A randomized, double-blind, crossover, placebo-controlled intervention study. The American Journal of Clinical Nutrition. 2008;87(3):785.

[94] Rabiu B, Jay A, Gibson G, Rastall R. Synthesis and Fermentation Properties of Novel Galacto-Oligosaccharides by beta-Galactosidases from Bifidobacterium Species. Applied and Environmental Microbiology. 2001;67(6):2526.

[95] Tzortzis G. Development and Evaluation Bimuno, a Novel Second Generation Prebiotic Galactooligosaccharide Mixture. Nondigestible Carbohydrates and Digestive Health. 2010:295-311.

[96] Tzortzis G, Goulas A, Gibson G. Synthesis of prebiotic galactooligosaccharides using whole cells of a novel strain, Bifidobacterium bifidum NCIMB 41171. Applied Microbiology and Biotechnology. 2005;68(3):412-6.

[97] Dubert-Ferrandon A, Nanthakumar, N., Rautava, S. et al. Direct immunomodulatory properties of galactooligosaccharides on TNF-a mediated inflammation in human intestinal epithelial cells. In: Paeschke TM, Aimutis WR, editors, Nondigestible Carbohydrates and Digestive Health. Ames, Iowa: Blackwell Publishing Ltd and Institute of Food Technologists; 2011. pp. 1-352.

[98] Searle LE, Cooley WA, Jones G, Nunez A, Crudgington B, Weyer $\mathrm{U}$, et al. Purified galactooligosaccharide, derived from a mixture produced by the enzymic activity of Bifidobacterium bifidum, reduces Salmonella Typhimurium adhesion 
and invasion in vitro and in vivo. Journal of Medical Microbiology. 2010;59(12):1428-39.

[99] DuPont AW, DuPont HL. The intestinal microbiota and chronic disorders of the gut. Nature Reviews Gastroenterology and Hepatology. 2011;8(9):523-31.

[100] Burr G, Hume M, Ricke S, Nisbet D, Gatlin D, 3rd. In vitro and in vivo evaluation of the prebiotics GroBiotic-A, inulin, mannanoligosaccharide, and galactooligosaccharide on the digestive microbiota and performance of hybrid striped bass (Morone chrysops x Morone saxatilis). Microbial Ecology. 2010;59(1):187-98.

[101] Nagel JE, Han K, Coon PJ, Adler WH, Bender BS. Age differences in phagocytosis by polymorphonuclear leukocytes measured by flow cytometry. Journal of Leukocyte Biology. 1986;39(4):399-407.

[102] Wenisch C, Patruta S, Daxbock F, Krause R, Horl W. Effect of age on human neutrophil function. Journal of Leukocyte Biology. 2000;67(1):40.

[103] Butcher SK, Chahal H, Nayak L, Sinclair A, Henriquez NV, Sapey E, et al. Senescence in innate immune responses: Reduced neutrophil phagocytic capacity and CD16 expression in elderly humans. Journal of Leukocyte Biology. 2001;70(6):881-6.

[104] Mariani E, Mariani AR, Meneghetti A, Tarozzi A, Cocco L, Facchini A. Age-dependent decreases of NK cell phosphoinositide turnover during spontaneous but not Fc-mediated cytolytic activity. International Immunology. 1998;10(7):981-9.

[105] Krishnaraj R, Bhooma T. Cytokine sensitivity of human NK cells during immunosenescence. 2. IL2-induced interferon gamma secretion. Immunology Letters. 1996;50(1-2): 59-63.

[106] Sindermann J, Kruse A, Frercks HJ, Schutz RM, Kirchner $\mathrm{H}$. Investigations of the lymphokine system in elderly individuals. Mechanisms of Ageing and Development. 1993;70(1-2):149-59.

[107] O'Mahony L, Holland J, Jackson J, Feighery C, Hennessy TP, Mealy K. Quantitative intracellular cytokine measurement: Age-related changes in proinflammatory cytokine production. Clinical Experimental Immunology. 1998;113(2):213-9.

[108] Rink L, Cakman I, Kirchner H. Altered cytokine production in the elderly. Mechanisms of Ageing and Development. 1998;102(2-3):199-209.

[109] Lahtinen SJ, Tammela L, Korpela J, Parhiala R, Ahokoski $\mathrm{H}$, Mykkanen H, et al. Probiotics modulate the Bifidobacterium microbiota of elderly nursing home residents. Age. 2009;31(1):59-66.

[110] Ahmed M, Prasad J, Gill H, Stevenson L, Gopal P. Impact of consumption of different levels of Bifidobacterium lactis HN019 on the intestinal microflora of elderly human subjects. Journal of Nutrition, Health \& Aging. 2007;11(1):26-31.
[111] Kalliomaki M, Salminen S, Arvilommi H, Kero P, Koskinen $\mathrm{P}$, Isolauri E. Probiotics in primary prevention of atopic disease: A randomised placebo-controlled trial. Lancet. 2001;357(9262):1076-9.

[112] Shen TY, Qin HL, Gao ZG, Fan XB, Hang XM, Jiang YQ. Influences of enteral nutrition combined with probiotics on gut microflora and barrier function of rats with abdominal infection. World Journal of Gastroenterology. 2006;12(27):4352.

[113] Majamaa H, Isolauri E. Probiotics: A novel approach in the management of food allergy. Journal of Allergy and Clinical Immunology. 1997;99(2):179-85.

[114] Demirer S, AydIntug S, AslIm B, Kepenekci I, Seng, 1 N, Evirgen O, et al. Effects of probiotics on radiation-induced intestinal injury in rats. Nutrition. 2006;22(2):179-86.

[115] Kleessen B, Sykura B, Zunft HJ, Blaut M. Effects of inulin and lactose on fecal microflora, microbial activity, and bowel habit in elderly constipated persons. The American journal of clinical nutrition. 1997;65(5):1397.

[116] Bouhnik Y, Achour L, Paineau D, Riottot M, Attar A, Bornet F. Four-week short chain fructo-oligosaccharides ingestion leads to increasing fecal bifidobacteria and cholesterol excretion in healthy elderly volunteers. Nutrition Journal. 2007;6(1):42.

[117] Walton GE, Van den Heuvel EGHM, Kosters MHW, Rastall RA, Tuohy KM, Gibson GR. A randomised crossover study investigating the effects of galacto-oligosaccharides on the faecal microbiota in men and women over 50 years of age. The British Journal of Nutrition. 2012;107(10):1466-75.

[118] Wang J, Sun B, Cao Y, Wang C. Wheat bran feruloyl oligosaccharides enhance the antioxidant activity of rat plasma. Food Chemistry. 2010;123(2):472-6.

[119] Ngo DN, Kim MM, Kim SK. Chitin oligosaccharides inhibit oxidative stress in live cells. Carbohydrate Polymers. 2008;74(2):228-34.

[120] Seidel C, Boehm V, Vogelsang H, Wagner A, Persin C, Glei $\mathrm{M}$, et al. Influence of prebiotics and antioxidants in bread on the immune system, antioxidative status and antioxidative capacity in male smokers and non-smokers. British Journal of Nutrition. 2007;97(2):349-56.

[121] Yen CH, Kuo YW, Tseng YH, Lee MC, Chen HL. Beneficial effects of fructo-oligosaccharides supplementation on fecal bifidobacteria and index of peroxidation status in constipated nursing-home residents-A placebo-controlled, diet-controlled trial. Nutrition. 2011;27(3):323-8.

[122] D'Souza A, Fordjour L, Ahmad A, Cai C, Kumar D, Valencia $\mathrm{G}$, et al. Effects of probiotics, prebiotics, and synbiotics on messenger RNA expression of caveolin-1, NOS, and genes regulating oxidative stress in the terminal ileum of formulafed neonatal rats. Pediatric Research. 2010;67(5):526-31. 